\title{
SCHMITSEK Szilvia
}

\section{Karrier/életút-támogató pályaorientációs rendszerek és szolgáltatások: folyamatos átalakulások egy átmeneti régióban. Három közép-kelet európai ország esete ${ }^{1}$}

\begin{abstract}
Recenzió a „Journal for Educational and Vocational Guidance” nevú rangos nemzetközi folyóiratban megjelent tanulmány bevezető részében a szerzők feltérképezik azt, hogy bár ezek az országok földrajzi szempontból Európa szívében találhatók és tagjai az Európai Uniónak (EU), valamint a Gazdasági Együttmúködési és Fejlesztési Szervezetnek (angolul Organisation for Economic Co-operation and Development, $\mathrm{OECD}$ ), mégis a nemzeti pályaorientációs szolgáltatásaik és rendszereik, valamint régiós együttmúködésük a pályaorientáció területén kevéssé ismertek ezen országok határain kívül.
\end{abstract}

Néhány elemzés bár készült a régió országait illetően (ELGPN, 2012; ETF, 2003; Watts \& Borbély-Pecze, 2011), de ezek főként bizonyos ágazatok teljesítményére koncentrálnak, mint például a foglalkoztatás, a felnőttképzés, a szakképzés vagy az iskolai pályatanácsadás. Ezáltal megállapíthatjuk, hogy ezek a tanulmányok hiányos képet nyújtanak a három ország pályaorientációs rendszerének céljairól és lehetőségeiről. A nemzeti vagy nemzetközi szakpolitikai ajánlások gyakran ugyanazokra a gyenge pontokra utalnak, anélkül, hogy figyelembe vennék a különféle ágazati szakpolitikáknak vagy a nemzeti pályaorientációs rendszerek elemeinek a kapcsolatát, illetve az egyes országok sajátos kontextusbeli jellemzőit. A szerzők azt is kiemelik, hogy az országok karrier/életút-támogató pályaorientáció rendszereinek jellegét, céljait és teljesítményét akkor ismerjük meg, ha mélyreható ismeretekkel rendelkezünk ezen országok kulturális örökségéről, amelyek kötődnek egy ország történelméhez.

A recenzált tanulmány a szlovák, a cseh és a magyar szerzők első közös vállalkozása egy közös platform építésére annak érdekében, hogy a közép-kelet-európai országok pályaorientációs szolgáltatásait és annak fejlődését leírják és értelmezzék. Az elemzés elsőként a szakképzési tanácsadási szolgáltatásokról a pályaorientációs szolgáltatásokra való áttérésre fókuszál a 19. század végétől kezdve, majd a kommunista rendszerre és annak változásaira (1989/1991) reflektál, és végül pedig a legutóbbi idők változásait mutatja be, vagyis a pályaorientációs szakpolitikáról az életút-támogató pályaorientációs szakpolitikákra való áttérést az EU-tagság kezdete óta (2004).

A cikk rámutat arra is, hogy a közép-kelet-európai országok számára a pályaorientációval kapcsolatos közös elvi sík kialakítása egy viszonylag újkeletű jelenség, mivel a regionális együttműködés az elmúlt 15 évben kezdődött. Egyik példája az Európai Pályaorientációs Szakpolitikai Hálózat (The European Lifelong Guidance Policy Network, ELGPN) keretein belüli közös munka (2007-2015), ami lehetővé tette a pályaorientációs rendszerek és szolgáltatások összehasonlító áttekintését. A másik fórum a közös gondolkodásra a Euroguidance $(E G)$ által szervezett határokon átnyúló szemináriumok. $A z$ ELGPN munkája átfogó eszköztárat biztosított az országos/regionális életút-támogató pályaorientációs szolgáltatások szisztematikus felülvizsgálatához. Jelenleg a CareersNet, az Európai Szakképzésfejlesztési Központ hálózata (CEDEFOP) további lehetőséget kínál a regionális szintű együttmúködésre. Ez a hálózat a CEDEFOP stratégiai dokumentumainak a kidolgozását is segíti olyan kérdésekben, mint a pályaorientációba történő befektetés. Bár a közép-kelet-európai országokból sok szakember vesz részt ezekben a szakmai hálózatokban, valamint nemzetközi pályaorientációs konferenciákon és megbeszéléseken a vasfüggöny leomlása óta, és követik a nemzetközi trendeket, gyakorlatokat, kutatásokat, még mindig nem halmoztak fel szakmai tudást a szomszédos országok fejlesztéseinek alapos tanulmányozásából.

\footnotetext{
1 T. B. Borbély-Pecze, L. Hloušková, T. Šprlák (2021): Career/lifelong guidance systems and services: continuous transformations in a transition region The case of three Central and Eastern European Countries. International Journal for Educational and Vocational Guidance https://doi.org/10.1007/s10775-021-09473-4.
} 
A szerzők definiálják, hogy mit is értenek Közép-Európa alatt földrajzi és gazdasági szempontból. Kiemelik, hogy az elmúlt évtizedek gazdasági fejleményei és a nyitott határok a schengeni zónában, valamint a különböző európai mobilitási eszközökhöz való hozzájutás (például az Erasmus +) olyan helyzetet teremtettek, amitől mind politikai, mind gazdasági értelemben a régió erősödött. Németország továbbra is a legfontosabb kereskedelmi és politikai partner, de a régió országai között szintén kialakultak a stratégiai kapcsolatok, makropolitikai szinten a V4 (Visegrádi négyes) csoport jó példa erre az érdeklődés-változásra.

A közép-kelet-európai államok meghatározása is sokrétű. Az OECD használja ezt a kifejezést, amit a következő országokra vonatkoztat: Albánia, Bulgária, Horvátország, a Cseh Köztársaság, Magyarország, Lengyelország, Románia, a Szlovák Köztársaság, Szlovénia és a három balti állam, Észtország, Lettország és Litvánia. Azonban a jelenlegi kutatás céljából a három balti állam és a balkáni országok (Albánia, Bulgária, Románia) nem tartoznak ide, mivel ezek az országok részben eltérő történelmi fejlődésen mentek keresztül. Azonban Ausztria, amely egy új entitássá alakult a Monarchia összeomlása után, és 1955-ben újra megújult, és azóta úgy hivatkoznak rá, mint közép-európai ország, éppen ezért szerepel ebben az elemzésben. Az eredeti név, a Habsburgok előtti Ausztria egyértelműen leírja státuszát, mivel Ostarrichi (996), azt jelenti „keleti állam”, mint keleti védelmi vonal.

A közép-kelet-európai nemzetek a Habsburg Birodalom részét képezték, miután a Cseh Királyság összeomlott a 13. század végétől (1274) és a Habsburg Birodalomba beolvadt. Így a "Mitteleuropa” (Közép-Európa) országok egy teljesen más történelmet tudhattak magukénak hosszú ideig, mint a földrajzilag Európa nyugati részén elhelyezkedő területek. Ausztria lett az egyetlen újonnan létrehozott ország, amely képes volt Európa nyugati részéhez közel kerülni az osztrák függetlenségi egyezmény eredményeként 1955-ben. Földrajzi értelemben azonban Közép-Európa sokszínúbb. Az első világháború előtti „Mitteleuropa” kielégítette a Habsburg Birodalom igényeit, amely elvesztette a hatalmát Németország egyesítésével. A második világháború után Magyarország és a régió a szovjet oldalra állt, kivéve Ausztriát. Ez a status quo 1991-ben a Szovjetunió összeomlása után ismét megváltozott, hozzájárulva ezen országok későbbi EU és a NATO tagságához az 1990-es évek végén és a 2000-es évek elején. 2004-ben a közép-kelet-európai országok uniós tagságot nyertek. A 2008-2009 közötti globális válság hatása jelentősen csökkentette a pluralista demokráciák támogatását a régióban. Egy „arany évtized” (2010-2019) gazdasági fejlődése után, a 2016-2018 közötti időszakban az átlagos nettó havi bérek euróban a következők voltak: 2410 EUR volt Németországban, 2217 Ausztriában, 932 EUR Csehországban, Szlovákiában 833 EUR, Magyarországon pedig 701 EUR. A legfrissebb Világ Boldogság Jelentés (World Happiness Report) szerint a közép-kelet-európai országokban az élet minőségének megítélése 2010 és 2019 között folyamatos és figyelemre méltó javulást mutatott. Azonban - tekintettel az összes geopolitikai változásra- az egyéni/háztartási szintű gazdasági biztonság és a kormányba vetett bizalom soha nem volt magas a régióban.

A tanulmány általános összehasonlító részének utolsó momentumaként kitér a régióra jellemző értékek és bizonytalansági faktorok bemutatására. A szerzők kiemelik, hogy a pályaorientációs szolgáltatások nemcsak az emberekkel és a pályaválasztásukkal állnak kapcsolatban, hanem a társadalom felépítésével és értékeivel, valamint a munkaerőpiac fajtájával és lehetőségeivel is. Ebben a tekintetben a kelet-közép-európai régió fejlődése és a régió jelenlegi lehetőségei eltérnek KözépEurópa nyugati részétől. Például az agyelszívás, vagyis a magasan kvalifikált munkaerő elvándorlása a munkaerőpiac egyik fő kihívása Közép- és Kelet-Európában. De nemcsak a magasan képzett, hanem minden típusú szakmunkás és a félképzett munkavállalók folyamatosan vándorolnak, főleg a német és az osztrák munkaerőpiac felé. Ennek egyik oka az, hogy az életszínvonal jelentősen alacsonyabb és az állampolgárok/családok foglalkoztatási esélyei is rosszabbak a közép- és kelet-európai országokban, mint Európa nyugati részén. Ezek a munka-erőpiaci strukturális jellemzők egy meglehetősen sajátos helyzetet és kihívásokat jelentenek a pályaorientáció/fejlesztési szakpolitikák szempontjából, valamint a rendszerfejlesztés és tanácsadási szolgáltatások nyújtása számára.

1981 óta a Globális Érték Felmérésének eredményei leírják a társadalmi értékeket a világ különböző régióiban. A közép- és kelet-európai régió tradicionális túlélési világrégióként van definiálva. Ez azt jelenti, hogy: 
- A hagyományos értékek hangsúlyozzák a vallás, a hagyományos családi értékek és az alkalmazkodás a hatalomhoz attitűd fontosságát. Ezeknek a társadalmaknak magasabb a nemzeti büszkeségük és a nacionalista szemléletük.

- A túlélési értékek a gazdasági és fizikai biztonságra helyezik a hangsúlyt.

A szakképzési tanácsadás/pályaorientációs szolgáltatások története egy régióban mindig összefügg a társadalmi és gazdasági fejleményekkel, ideértve a munkaerőpiac struktúráját és szükségleteit, valamint a szakképzés és az oktatás változó küldetését.

A cikk második átfogó része betekintést nyújt a három vizsgált ország pályaorientációs rendszereinek történeti és szakmai alakulásába. A szerzők kitérnek a legfontosabb fordulópontokra a 19. század második felétől. Megemlítik, hogy a monarchia területén a szakképzési tanácsadás iránti igény egyértelművé válaszként jelent meg a növekedő városi munkanélküliségre és a képzetlen vidékről jövő munkások áramlására. A szakképzési tanácsadás intézményesülésének oka a munka/munkanélküliség változó megítélése volt a századfordulón. A munkahelyek nemcsak az egyén megélhetését fedezték, hanem egyfajta javak is voltak. Éppen ezért a munkanélküliség nem az egyéni felelősség függvénye volt, hanem eredetét a nehezen megjósolható gazdasági válságokban látták. Ezek a strukturális változások a munkaerőpiacon rámutattak arra, hogy a hagyományos szegénygondozáson túli eszközök bevezetésére lesz szükség. Különböző szakképzési tanácsadás szolgáltatások alakultak ki az úgynevezett Cisleithaniában (többnyire mai Csehország), és az úgynevezett Transleithaniában (magyar királyság, többnyire a mai Szlovákia). Transleithaniában a szakképzési tanácsadás első intézményesített formája 1899-re nyúlik vissza, amikor Ranschburg Pál megalapította első szakpszichológiai laboratóriumát Budapesten. Néhány évvel később a szakképzésről/tanoncképzésről szóló első törvényt fogadta el a parlament. A másik fontos állomás a Szondi Lipót-féle Magyar Királyi Állami Gyógypedagógiai Kórtani és Gyógytani Laboratóriumának megalapítása volt, ami szakképzési tanácsadási intézményként is funkcionált. 1912-ben Budapesten az alpolgármester megnyitotta a városi szakképzési tanácsadás intézetét. Az Osztrák-Magyar Monarchia összeomlása után pedig megalapították a Pedagógiai és Szakképzési Tanácsadás Országos intézetét. Ahogy Magyarország belépett a II. világháborúba, új szakmai tanácsadó intézmény nyílt Mérei Ferenc vezetésével, ami a szovjet megszállásig múködött.

Cisleithaniában a közigazgatás a foglalkoztatási szolgálatokat integrálta a jogrendszerbe a munkanélküliség kezelésére. A munkaügyi hivatalok elődjeit megalapították 1903-ban, ahol ingyenes információszolgáltatás volt, valamint tanácsadás és közvetítés a munkaadók és a munkakeresők között. Ebben az időszakban a másik fontos szakmai hatás a szakképzési tanácsadásra a szakmai tanácsadási centrumok munkája volt.

Az első világháború végén a közép-kelet-európai államhatárok drasztikusan megváltoztak. Új államok jöttek létre, pl. Magyarország és Ausztria, valamint egy új ország, Csehszlovákia. A német-osztrák gyökerü pszichológusok továbbra is meghatározó alakjai maradtak az újonnan kialakult országok számára, mint pl. Wilhelm Maximilan Wundt, Alfred Adler, Viktor Frankl és Sigmund Freud.

Az 1918-ban megalakult Csehszlovákiában jóváhagyták az iránymutatásokat arra vonatkozólag, hogy munkaügyi tanácsadó centrumok jöjjenek létre álláskeresők számára. Az első szakképzési tanácsadó intézet, ami első munkahelyeket keresett tanoncoknak Brnóban jött létre 1919-ben. Ezen kívül nyíltak hasonló profilú intézetek országszerte, a prágai volt különösen fontos, mert a Központi Pszichotechnikai Intézet részévé vált, ahol az egyének pszichés és fizikai adottságait vizsgálták, aminek segítségével az érintetteknek próbáltak megfelelő szakmát ajánlani. Az itt folyó munka megalapozta a munkapszichológia mint önálló szakterület kialakulását. Szlovákiában is hasonló volt a helyzet, vagyis létrejött az első tanácsadó központ 1928-ban a pozsonyi Pszichotechnikai Intézet részeként, később pedig az Emberi Munka Intézetének részévé vált, ahol a munka pszichológiáját és a pályaorientációt kutatták. E központok fő célja volt, hogy szakmát vagy karrierlehetőséget ajánljanak az egyén számára pszichotechnikai/orvosi tesztek eredményei alapján. Érdekes, hogy ezeknek a központoknak a munkatársai elsősorban átképzett tanárok voltak, nem pszichológusok. Ezen kívül állami foglalkoztatási irodák voltak országszerte. A II. világháború után a szakképzési tanácsadási 
szolgáltatások fejlesztését befolyásolta az a tény, hogy Csehszlovákia szovjet befolyás alá került, ezáltal a munkaviszony kötelező jellege került a középpontba. A munkaerő-toborzás átalakult egy olyan intézkedéssé, amivel az egyéneket átirányították olyan területekre, amit a gazdasági terv diktált. Ezzel és a Munkavédelmi és Szociális Gondozási Minisztérium bezárásával a szakképzési tanácsadási szolgáltatásokat megszüntették. A 60-as években megpróbálták visszaállítani a szakképzési tanácsadó szolgáltatásokat regionális pedagógia-pszichológiai intézetek alapításával, ahol pályaorientáció is folyt. Ezekben az intézetekben egy új trend alakult ki, vagyis a pedagógiai tanácsadás, ami részévé vált az életpálya-építési készségek fejlesztésének az oktatásban és a pedagógiai-pszichológiai tanácsadásnak. Az iskolákban is tesztelték az életpálya-építési készségek fejlesztését, ami sikeresnek is bizonyult. A gimnáziumokban alkalmaztak pedagógiai tanácsadókat. Szlovákia is próbálkozott a 60 -as években a prágai modell bevezetésével, de ez sajnos nem járt sikerrel. A 70-es években a regionális/kerületi pedagógiai és pszichológiai centrumokra is kiterjesztették az életpálya-építési készségek fejlesztését, amely megalapozta a tanácsadó szolgálatok létét az oktatási rendszerben. A tanácsadók a centrumokban elsősorban tanácsadó pszichológusok voltak. A pedagógiai tanácsadók, eredendően tanárok, a középiskolákban információkat szolgáltattak és ők voltak felelősek a karrieroktatásért is. A cseh és a szlovák „pszichológiai-pedagógiai tanácsadás” koncepciójának a definiálása különbözött egymástól. Összességében azonban elmondható, hogy a pedagógiai-pszichológiai centrumok elsősorban azoknak a fiataloknak segítettek a pályaválasztásban, akik valamilyen szempontból problémásnak bizonyultak.

A következő jelentős fordulópontot 1993 hozta, mikor Csehszlovákiából megalakult a Cseh és a Szlovák Köztársaság. Az új Csehországban a pályaorientációnak elsősorban annyi volt a szerepe, hogy felszámolja a társadalmi átalakulás negatív hatásait, amelyek befolyásolták az egyén életét. $\mathrm{A}$ pályaorientációs szolgáltatások az Oktatási, Ifjúsági és Sport Minisztérium alá tartoztak, és nagyjából olyanok maradtak funkciójukat tekintve, mint a szocializmusban voltak. A munkanélküliség problémájával a Munkaügyi Minisztérium irányítása alatt álló munkaügyi központok foglalkoztak. Ezek nemcsak a munkanélkülieknek adtak karrier tanácsadást, hanem felsős és középiskolai diákoknak is. Ez a feladatmegosztás azt eredményezte, hogy egymás mellett párhuzamosan két rendszerben, vagyis az oktatás területén és a foglalkoztatási szolgálatokban is fejlődött a pályaorientáció.

Az 1990-es évek második felétől a gazdasági, foglalkoztatási és oktatási szakpolitikák kapcsolódtak a nemzeti EU-csatlakozási programhoz. Ez együttműködésre adott lehetőséget az oktatási és a munkaügyi tárca között, aminek köszönhetően megtörtént a szakképzési tanácsadás és a pályaorientáció innovációja, valamint az általános és középiskolák tanterveiben kötelezővé vált a karrieroktatás. A pályaorientáció innovációját elsősorban helyi érdekek motiválták, és nem a nemzetközi trendek, amelyek a pályaorientációt elmozdították volna az életút-támogató pályaorientáció felé.

A cseh kormány számára a jelenlegi kihívás az, hogy miként alakítsák át a kettős minisztérium irányítása alatt álló pályaorientációs szolgáltatásokat az egész életen át tartó tanulás-tanácsadás rendszerére. Az oktatási rendszerben kihívást jelent pl. a korai iskolaelhagyók aránya és az iskolán kívüli pályaorientáció innovációja. A munkaerőpiacon bár alacsony a munkanélküliek aránya, mégis szükség lenne több figyelmet szentelni a munkavállalókkal kapcsolatos állami karrier-tanácsadó szolgáltatásokra. Összességében elmondható, hogy az 1990-es években létrehozott kettős irányítású pályaorientációs szolgáltatások továbbra is fennmaradtak, ami további kihívásokat jelent az életút-támogató pályaorientációs politikák fejlesztésével kapcsolatban.

Szlovákia jelenlegi helyzetét is ismerteti a cikk, amiben kitér arra, hogy a munkaerőpiacon kedvezőtlen tendenciák tapasztalhatók az egymást követő kormányok privatizáción alapuló neoliberális politikája miatt, pl. a munkabérek alacsonyak, ezzel szemben pedig a munkaórák száma a legmagasabb az EUban. Az alacsony munkanélküliség és bizonyos hiányszakmák a munkaerőpiacon azt erősítik, hogy a pályaorientáció mint szolgáltatás elsősorban a munkaerőpiac igényeinek van alárendelve. A szlovák oktatási rendszer nem tekinthető inkluzívnak, jellemző a területi és szociális egyenlőtlenségek növekedése, valamint nagymértékű a roma tanulók szegregációja és lemorzsolódása. A pályaorientációt az általános és középiskolákban pedagógiai tanácsadók végzik, a nevelési 
centrumokban (82állami és 12 magán) pedig pszichológusok tartanak pedagógiai és pszichológiai tanácsadást. Az európai uniós pályázati forrásoknak köszönhetően 2008 és 2016 között tanácsadó eszközöket, módszereket és tréning anyagokat fejlesztettek pályaorientációs szakembereknek. Ennek ellenére a rendszer kapacitását nem sikerült bővíteni, és a pályaorientációs szakemberek is nagyon kevés óraszámban tudnak jelen lenni a közoktatási intézményekben. A pályaorientációval kapcsolatos tantárgyakat nem tanítanak, és a tantervbe sincsenek sikeresen integrálva. Az EU Szociális Alap (ESZA) egyik futó projektjétől várják, hogy a pályaorientációs szakemberek mind az iskolákban, mind a regionális központokban hatékonyabban tudjanak dolgozni. A felsőoktatásban 2002-től van pályaorientációs tanácsadás, de ez a gyakorlatban hatékonyan csak néhány egyetemen múködik. $\mathrm{A}$ foglalkoztatási szervezeteknél az ESZA projekteknek köszönhetően 2017-19 között voltak célzott karrier-tanácsadási programok hátrányos helyzetű csoportoknak. 2020-ra 300 tanácsadó végez karriertanácsadási szolgáltatásokat 46 regionális központban. Ennek ellenére a dolgozó felnőttek limitáltan jutnak karrier-tanácsadáshoz. Szlovákiában a különböző érdekelt felek egyre inkább felismerik, hogy fontos a pályaorientáció szerepe és szakmai sztenderdjeinek kidolgozása.

Magyarország pályaorientációval kapcsolatos történetét is bemutatja a cikk 1919-től napjainkig. Megemlítésre kerül Ferenczi Sándor, Stein Fülöp és Szondi Lipót ún. budapesti pszichológiai iskolája, és az 1920-as évek változásai, mint például a nemzeti társadalombiztosítás által létrehozott munkaképességet vizsgáló részleg. A második világháború éveiben Budapest városi pszichológiai tanácsadó központot hozott létre. 1947 és 1959 között a pedagógia, pszichológia és a tanácsadás tiltott szakterületek voltak. 1959-ben az újonnan felállított Munkaügyi Minisztérium otthont adott egy kis szakképzési pszichológiai részlegnek, amely újraindította a karrier tanácsadást az országban. A 70-es évek elejétól az 1980-as évek közepéig, a pályaorientáció új aranykora volt, amikor a kormány létrehozta a nemzeti ifjúsági pályaorientációs központot és húsz megyei intézetet, amik támogatták a középfokú oktatásba való átmenetet. Ezt a rendszert az 1980-as években szüntették meg. 1988/89-től jelentős gazdasági és politikai változások voltak, amik életre hívtak új pályaorientációs szolgáltatásokat. 1990-ben megalakult a Országos Munkaügyi Hivatal, ahol képzett szakemberek voltak és a karriertanácsadás szűk megközelítését alkalmazták, válaszul a tömeges munkanélküliség megjelenésére. Az új pályaorientációs tanácsadók képzése 1992-től kezdődött a gödöllői egyetemen. 2010 után a Magyar Állami Foglalkoztatási Szolgálat helyzete megváltozott, mivel a kormány elkezdte gyengíteni az ország munkaügyi igazgatását. A jelenlegi kormány 11 éve van az ország élén, 2/3-os parlamenti többségével vezeti az országot. 2008 óta nőtt a foglalkoztatás és a GDP, ami egy viszonylagos biztonságérzetet nyújt az átlagos állampolgároknak. Ezáltal nagyon minimális a nemzeti pályaorientációs szolgáltatások fejlesztése, az a kevés fejlesztés, ami van, pedig a hátrányos helyzetű csoportok támogatására koncentrál. Jellemző hátránykompenzáló intézkedésként jelenik meg a fiatalok beterelése a szakképzésbe. Viszont az általános, életpálya váltásokat támogató pályaorientációs szolgáltatások fejlesztésére nem nyitott a jelenlegi szakpolitika. A másik elhanyagolt terület, a munkanélküliek ellátása, ugyanis álláskeresési támogatás csak 3 hónapig jár, ami a legrövidebb időintervallum az EUban. A munkaképes korú népesség 7\% -kal csökkent 2001 és 2017 között, ami az ország pozícióját gyengíti. A kormányzati szándék a pályaorientációs szolgáltatások és a szakpolitika fejlesztésével kapcsolatban hosszú ideje hiányzik. A Magyar Nemzeti Pályaorientációs Tanácsot 2012-ben megszüntették. 2010 óta nincs munkaügyi minisztérium vagy oktatási minisztérium a miniszteri struktúrákon belül. A jelenlegi minisztériumok gyakran széles portfóliókat fednek le. Nincsenek átlátható, rendelkezésre álló nyilvános adatok sem pl. a pályaorientációs szakemberek számát és az ellátási feladatok leosztására vonatkozólag. A legutóbbi általános választások (2018) után új gazdasági minisztérium jött létre Innovációs és Technológiai Minisztérium címmel, amely integrálja a felsőoktatást, a felnőttoktatást, a szakképzést és a foglalkoztatási politikákat. A minisztérium „Szakmai Oktatás, képzés és felnőttképzés 4.0 "stratégiája egy alfejezetet szentel a pályaorientációnak, amiből hiányzik az egész életen át tartó pályaorientáció perspektívája. Összefoglalva elmondható, hogy életúttámogató pályaorientációs rendszerek/szolgáltatások és a karrieroktatás megvalósítása a mindennapi gyakorlatban még mindig várat magára a magyar policy környezetben.

A tanulmány konklúziójaként megállapítható, hogy a három vizsgált országban nincsenek nemzeti, életút-támogató tanácsadási stratégiák, és a különböző szektorok (főként az oktatás és a 
foglalkoztatás) közötti együttmúködés is eseti. A karrierépítés egész életen át tartó koncepciója nem jelent meg az intézményi gyakorlatokban. Ennek ellenére úgy túnik, hogy a nemzeti kormányok elégedettek országaik és a rendszer értékeléseivel, amelyeket a különböző európai ügynökségek, az OECD vagy a World Bank készítenek. Habár a legtöbb kritika ezekben a jelentésekben arra irányul, hogy nincsenek befogadó, minden életkort lefedő pályaorientációs rendszerek, viszont a politikai döntéshozók ezeket a fontos kritikai érveket még cselekvési pontként sem ismerik el. 